\title{
Versatile Cell-Free Protein Synthesis Systems Based on Chinese Hamster Ovary Cells
}

\section{Lena Thoring and Stefan Kubick}

\begin{abstract}
We present an alternative production platform for the synthesis of complex proteins. Apart from conventionally applied protein production using engineered mammalian cell lines, this protocol describes the preparation and principle of cell-free protein synthesis systems based on $\mathrm{CHO}$ cell lysates. The $\mathrm{CHO}$ cellfree system contains endogenous microsomes derived from the endoplasmic reticulum, which enables a direct integration of membrane proteins into a nature like milieu and the introduction of posttranslational modifications. Different steps of system development are described including the cultivation of $\mathrm{CHO}$ cells, cell harvesting and cell disruption to prepare translationally active $\mathrm{CHO}$ cell lysates. The requirements for DNA templates and the generation of linear DNA templates suitable for the $\mathrm{CHO}$ cell-free reaction is further depicted to underline the opportunity to produce different protein variants in a short period. This experimental setup provides a basis for high-throughput applications. The productivity of the CHO cellfree systems is further increased by using a non-canonical translation initiation due to the attachment of an internal ribosomal entry site of the Cricket paralysis virus (CRPV IRES) to the 5' UTR of the desired gene. In this way, a direct interaction of the IRES structure with the ribosome facilitates a translation factor independent initiation of translation. Cell-free reactions were performed in fast and efficient batch reactions leading to protein yields up to $40 \mu \mathrm{g} / \mathrm{mL}$. The reaction format was further adjusted to a continuous exchange $\mathrm{CHO}$ cell-free reaction $(\mathrm{CHO} \mathrm{CECF})$ to prolong reaction time and thereby increase the productivity of the cell-free systems. Finally, protein yields up to $1 \mathrm{~g} / \mathrm{L}$ were obtained. The CHO CECF system represents a sophisticated resource to address structural and functional aspects of difficult-to-express proteins in fundamental and applied research.
\end{abstract}

Key words Cell-free protein synthesis, $\mathrm{CHO}$ cells, Continuous exchange cell-free systems, Difficultto-express proteins, In vitro protein production, Internal ribosomal entry sites, Linear expression templates

\section{Introduction}

Nowadays, protein synthesis plays a pivotal role in the pharmaceutical industry for the development and screening of novel therapeutical treatments and the production of drugs. There is an increasing demand of fast and efficient protein production platforms, while different cellular host organisms are conventionally 
used for the production of a target protein $[1,2]$. One of the currently most relevant production hosts are Chinese hamster ovary (CHO) cells, a well-established, optimized, safe, and reliable production host for more than three decades $[3,4]$. The development of appropriate cell hosts comprises a laborious and timeconsuming developmental process and is limited for proteins, which show cytotoxic effects and folding issues during cellular overexpression. Membrane proteins and proteinogenic toxins belong to this class of so-called "difficult-to-express" proteins. Despite their challenging production process, these proteins harbor a high potential for pharmaceutical applications $[5,6]$. In this context, novel protein productions platforms so called cell-free protein synthesis systems are continuously developed to provide a value-added technology. Cell-free protein synthesis system are typically based on cell lysates harboring the entire translational machinery in an active state $[7,8]$. Until now, a broad range of cell-free protein synthesis systems has been developed differing in their cellular origin and their performance [9]. In general, the systems can be subdivided into prokaryotic and eukaryotic cellfree systems, while the selection of the production platform depends on the complexity of the desired target protein [10]. Eukaryotic cell-free protein synthesis systems are generally used for the production of pharmaceutically relevant and complex mammalian proteins. Special eukaryotic cell-free systems contain endogenous microsomes derived from the endoplasmic reticulum due to a mild cell disruption procedure during lysate preparation. Microsomes enable an integration of membrane embedded and associated proteins into a nature-like milieu, a cotranslational translocation of proteins as reported in cellular protein expression processes and they harbor a fully ER based set of enzymes for folding and posttranslational modifications including relevant glycosyltransferases for attachment of glycan moieties, chaperones and essential molecules for the introduction of disulfide bridges [11-14]. In order to combine a mammalian host cell often used for the production of versatile, mammalian proteins and a cell-free platform, we have recently developed novel systems based on the prominent industrial protein production host $\mathrm{CHO}$ cells $[15,16]$. This platform provides a user-friendly system completing the classical industrial protein production pipeline. The fast, efficient, and high-throughput compatible protein synthesis tool promotes DNA template pre-evaluation as well as production of difficult-to-express proteins [17]. To realize these demands a coupled transcription/translation system is developed containing endogenous microsomal structures for posttranslational modifications and cotranslational membrane protein integration. To address individual applications, the system is adapted to different reaction modes including a fast batch based [18] and a highly productive continuous exchange cell-free system (CECF) leading to protein 
yields up to $1 \mathrm{~g} / \mathrm{L}$ [19]. A concept is proposed for the application of linear DNA templates apart from circular DNA to expand the platform by a fast and cloning-free DNA template generation process.

This chapter includes an overview covering the entire process pipeline for the development of $\mathrm{CHO}$ cell-free systems. In this protocol, we present the preparation of cell-free systems containing the cultivation of $\mathrm{CHO}$ cells, the preparation of translationally active lysate, the generation of linear expression templates and finally the cell-free production of proteins using batch and CECF formatted systems.

\section{Materials}

\subsection{Cell Cultivation}

1. CHO-Kl cells are purchased from a cell bank (DSZM, Germany) and adapted to serum-free suspension cultivation (see Note 1).

2. For the initial cultivation of the CHO cells, shake flasks (Corning) of different sizes (from $125 \mathrm{~mL}$ up to $1 \mathrm{~L}$ ) are used.

3. Cell density and viability are evaluated using a Thoma cell counting chamber and trypan blue staining.

4. $\mathrm{CO}_{2}$-Incubator Multitron (Infors) for cultivation of $\mathrm{CHO}$ cells in shake flasks.

5. Conventional stirred tank bioreactors in a scale of $5 \mathrm{~L}$ (Biostat B-DCUII, Sartorius Stedim Biotech GmbH) up to $30 \mathrm{~L}$ (Biostat D-DCU) including an aeration basket for bubble-free aeration (see Note 2). An internal spin filter is implemented to enable perfusion based fermentation.

6. Diverse sensor units for online monitoring of cell cultivation process: $\mathrm{pH}$ probe, $\mathrm{pO}_{2}$ probe, level sensor (Hamilton and Sartorius Stedim Biotech $\mathrm{GmbH}$ ).

7. MFCS SCADA software (bioprocess control) (Sartorius Ste$\operatorname{dim}$ Biotech GmbH) (see Note 3).

8. 1 M Sodium carbonate solution (Sigma-Aldrich) for the adjustment of $\mathrm{pH}$ during fermentation.

9. Chemically defined PowerCHO2CD medium (Lonza) supplemented with $6 \mathrm{mM}$ stabilized glutamine (Sigma-Aldrich).

10. Wash and resuspension buffer: $40 \mathrm{mM}$ HEPES-KOH (pH 7.5), $100 \mathrm{mM} \mathrm{NaOAC}$ and $4 \mathrm{mM}$ DTT. Store at $4{ }^{\circ} \mathrm{C}$.

11. Light microscope BX40 and Cell D Software (Olympus) (see Note 4). 
2.2 Cell Disruption and $\mathrm{CHO}$ Lysate Preparation

\subsection{Generation} of Suitable Linear and Circular DNA Expression Templates
1. Wash buffer (see Subheading 2.1, item 9).

2. Syringe with 20-gauge needle or high-pressure homogenizer.

3. Nanodrop 2000c (Thermo Scientific).

4. Sephadex G-25 columns (NAP 25 or Äkta Prime (GE-Healthcare)). Stored at $4{ }^{\circ} \mathrm{C}$.

5. S7 Nuclease (Roche) $(200 \mathrm{U} / \mu \mathrm{L})$. Stored at $-20^{\circ} \mathrm{C}$.

6. $80 \mathrm{mM} \mathrm{CaCl}_{2}$ and $80 \mathrm{mM} \mathrm{EGTA} \mathrm{dissolved} \mathrm{in} \mathrm{water} \mathrm{and} \mathrm{stored}$ at $4{ }^{\circ} \mathrm{C}$.

7. Creatine kinase dissolved in water $(1 \mathrm{mg} / \mathrm{mL})$ and stored at $-20{ }^{\circ} \mathrm{C}$.

8. Baker's yeast tRNA $(17.5 \mu \mathrm{g} / \mathrm{mL})$ dissolved in water and stored at $-80{ }^{\circ} \mathrm{C}$.

9. High speed centrifuge (Beckmann Coulter) for cell harvesting.

1. Sequence of the gene of interest (GOI).

2. Regulatory sequence donor vector containing the $5^{\prime}$-terminal regulatory sequences necessary for $\mathrm{CHO}$ cell-free synthesis (see Note 5).

3. T7 RNA polymerase promotor ( $5^{\prime}$ UTR) and terminator $\left(3^{\prime}\right.$ UTR) sequence.

4. Sequence of the Cricket paralysis virus (CRPV) IGR IRES (Genbank accession no. AF218039, nucleotides 6025-6216).

5. Gene specific primer pairs for the amplification of the gene of interest and the attachment of regulatory overlap sequences (see Note 6).

6. Regulatory adapter primers (Reg-F, Reg-R, CRPV-R) for the introduction of required regulatory sequences.

7. PCR thermocycler (Bio-Rad).

8. HotStar HiFidelity DNA Polymerase and appropriate buffer including dNTPs (Qiagen) ( see Note 7).

9. Perfect Blue Gel System and universal Agarose (Peqlab).

10. Rotiphorese 10× TBE-buffer (Carl Roth).

11. DNA Stain Clear G (SERVA).

12. 2-log DNA ladder 0.1-10 kb (NEB).

13. EasyXpress pIX3.0 cell-free expression vector backbone for direct cloning of generated PCR products into a circular plasmid applicable for cell-free protein synthesis (Biotechrabbit) (see Note 8).

14. Plasmids including the gene of interest suitable for cell-free protein synthesis (Geneart Gene Synthesis service (Thermo Fisher Scientific) or BioCat). 
15. Electroporation device and cuvettes (Biorad).

16. E.coli JM109 strain (New England Biolabs).

17. LB media (Carl Roth).

18. Antibiotics (Sigma-Aldrich).

19. PureLink HiPure Plasmid Prep Kit (Thermo Fisher Scientific).

20. Restriction enzymes for the verification of target gene integration into a plasmid.

21. Nanodrop C for the estimation of plasmid DNA concentration.

22. Primers for DNA sequencing: M13-F5' GTA AAA CGA CGG CCA GTG3', MI3-R 5' CAG GAA ACA GCT ATG AC 3'.

\subsection{Batch Formatted CHO Cell-Free Synthesis of Proteins}

1. $1.5 \mathrm{~mL}$ reaction tubes.

2. Thermomixer comfort (Eppendorf).

3. Previously prepared $\mathrm{CHO}$ lysate. Store at $-80{ }^{\circ} \mathrm{C}$.

4. Translation buffer $(10 \times): 300 \mathrm{mM}$ HEPES-KOH $(\mathrm{pH} 7.6)$, $2250 \mathrm{mM}$ KOAc, $2.5 \mathrm{mM}$ spermidine, $25 \mathrm{mM}$ of DTT, $1 \mathrm{mM}$ of each of the 20 canonical amino acids (Merck) and $39 \mathrm{mM} \mathrm{Mg}(\mathrm{OAc})_{2}$. Store at $-80{ }^{\circ} \mathrm{C}$ (see Note 9).

5. Energy buffer $(5 \times): 100 \mathrm{mM}$ creatine phosphate, $8.75 \mathrm{mM}$ ATP, $1.5 \mathrm{mM}$ CTP, $1.5 \mathrm{mM}$ UTP, $1.5 \mathrm{mM} \mathrm{GTP}$ (Roche), and $0.5 \mathrm{mM}$ $\mathrm{m}^{7} \mathrm{G}(\mathrm{ppp}) \mathrm{G}$ cap analogue. Store at $-80{ }^{\circ} \mathrm{C}$ ( see Note 9).

6. T7 RNA polymerase $(3 \mathrm{U} / \mu \mathrm{L})$ for performing the transcription reaction in the transcription-translation coupled system. Store at $-20{ }^{\circ} \mathrm{C}$.

7. ${ }^{14} \mathrm{C}$ Leucine (PerkinElmer) (final concentration of $66.67 \mathrm{dpm} /$ $\mathrm{pmol}$ ) for radiolabeling of proteins. Store at $-20^{\circ} \mathrm{C}$.

8. Linear expression template or plasmid DNA containing the GOI. Store at $-20^{\circ} \mathrm{C}$.

1. Two chamber dialysis device (Membrane cut-off: $10 \mathrm{kDa}$, $50 \mu \mathrm{L}$ reaction chamber, $1000 \mu \mathrm{L}$ feeding chamber) (Biotech Rabbit).

2. Thermomixer $\mathrm{C}$ (Eppendorf).

3. Translationally active $\mathrm{CHO}$ lysate. Store at $-80^{\circ} \mathrm{C}$ ( $\sec$ Note 9$)$.

4. Translation buffer $(10 \times)$ (see Subheading 2.5 , item 4$)$.

5. Energy buffer: Energy buffer $(5 \times)$ containing the following components: $92.5 \mathrm{mM}$ creatine phosphate, $8.75 \mathrm{mM}$ ATP, $1.5 \mathrm{mM}$ CTP, $1.5 \mathrm{mM}$ UTP, $1.5 \mathrm{mM}$ GTP (Roche). Store at $-20^{\circ} \mathrm{C}$.

6. T7 RNA polymerase $(1 \mathrm{U} / \mu \mathrm{L})$ for performing the transcription reaction in the transcription-translation coupled system. Store at $-20^{\circ} \mathrm{C}$. 
7. Caspase inhibitor AC-DEVD CMK (Santa Cruz Biotechnology) diluted in water (see Note 10).

8. $2500 \mathrm{mM} \mathrm{Mg}(\mathrm{OAc})_{2}$ in water. Store at $-20{ }^{\circ} \mathrm{C}$.

9. ${ }^{14} \mathrm{C}$ Leucine (PerkinElmer) (final concentration of $66.67 \mathrm{dpm} / \mathrm{pmol}$ ) for radiolabeling of proteins. Store at $-20{ }^{\circ} \mathrm{C}$.

10. Linear expression template or plasmid DNA containing the GOI. Store at $-20{ }^{\circ} \mathrm{C}$.

3 Methods

3.1 Biomass Production
1. $\mathrm{CHO}-\mathrm{Kl}$ cells are initially cultured in shake flask starting with a density between 0.5 and $0.7 \times 10^{6}$ cells $/ \mathrm{mL}$. Cultivation conditions are set to a temperature of $37^{\circ} \mathrm{C}$, a $\mathrm{CO}_{2}$ concentration of $5 \%$ and a shaking speed of 100 RPM.

2. For biomass production the stirred tank bioreactor is inoculated with $\mathrm{CHO}-\mathrm{Kl}$ cells precultured in shake flasks at an initial density of around $1.0 \times 10^{6}$ cells $/ \mathrm{mL}$.

3. The fermentation process can be performed in repeated batch or perfusion mode. The repeated batch process included a cell growth phase of approximately 2 days to obtain cell densities between 4 and $5 \times 10^{6}$ cells $/ \mathrm{mL}$ grown in the exponential growth phase, which is followed by the cell harvest.

4. A defined volume of cell suspension remains in the cultivation vessel to start a second cycle of batch cultivation. The repeated batch is performed for 3 cycles.

5. To increase the produced biomass, a perfusion fermentation process can be applied to the $\mathrm{CHO}$ cell lysate preparation protocol. For this, $\mathrm{CHO}$ cells are inoculated at a density of $1 \times 10^{6}$ cells $/ \mathrm{mL}$, a batch based process is performed until a density between $3-4 \times 10^{6}$ cells $/ \mathrm{mL}$ is reached and perfusion mode is started using a perfusion rate of $0.5 \mathrm{RV} /$ day (RV: reactor volume).

6. Exponentially grown $\mathrm{CHO}$ cells can be harvested at different cell densities during the perfusion process without the loss of translational activity of CHO cell lysate (Fig. 1).

1. Exponentially grown $\mathrm{CHO}$ cells are harvested by centrifugation using a fixed angle rotor or a continuous flow rotor depending on the volume of cell suspension.

2. After harvesting cells are washed with HEPES based wash buffer (see Subheading 2.1, item 9) to remove culture medium components.

3. Before cell disruption, $\mathrm{CHO}$ cells are suspended in wash buffer to obtain a final density of approximately $1.0 \times 10^{8}$ cells $/ \mathrm{mL}$. 
A

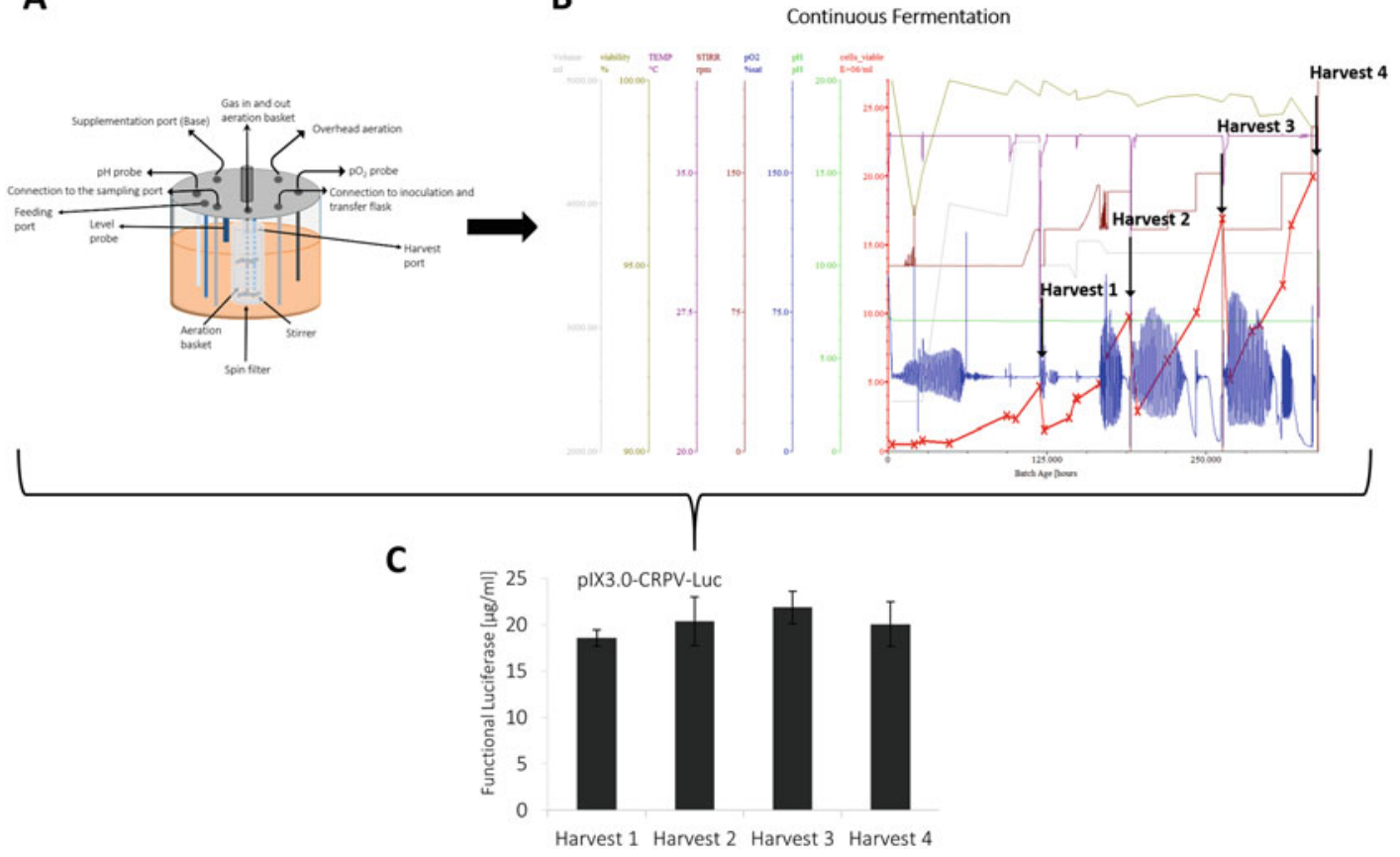

Fig. 1 Application of continuous fermentation for $\mathrm{CHO}$ biomass production used for the preparation of $\mathrm{CHO}$ cell-lysates. $\mathrm{CHO}$ cells are cultured in a $5 \mathrm{~L}$ cultivation vessel connected to a Biostat B-DCU II regulation unit (Sartorius Stedim). Different regulation and monitoring systems are connected to the fermentation vessel including a level probe, $\mathrm{pH}$ sensor, and $\mathrm{pO}_{2}$ sensor as illustrated in (a). Continuous cultivation is realized by the introduction of a spin filter for cell retention and implementation of several pumps to enable feeding with fresh culture medium and removal of inhibitory byproducts. The perfusion process is started at a cell density of around $4 \times 10^{6} \mathrm{cells} / \mathrm{mL}$ and a perfusion rate of 0.5 reactor volumes/day. Fermentation parameters are monitored using MFCS SCADA software (b). CHO cell densities and viabilities are estimated by a Thoma counting chamber and trypan blue staining. Cells are harvested at different cell densities to evaluate the possibility to use high cell-density cultures for production of translationally active $\mathrm{CHO}$ cell lysate. Times of harvest are indicated by black arrows. (c) shows the quality of the produced $\mathrm{CHO}$ cell lysate analyzed using batch formatted cell-free protein synthesis. Quality control was based on the cell-free protein synthesis of model protein luciferase (DNA template: pIX3.0-CRPV-Luc) and analysis of luciferase activity using a standard luciferase assay (Promega) and luminescence detection using a multimode microplate reader (Berthold). Protein yield was calculated by application of a previously prepared calibration curve. Error bars indicate one standard deviation ( $n=6$, harvests 1 and $4 ; n=12$, harvests 2 and 3 ). No significant differences in luciferase activity were detected using $\mathrm{CHO}$ cell lysates harvested at different cell densities showing the possibility of using high cell-density cultures for lysate production

4. For preparation of translationally active $\mathrm{CHO}$ lysate, which contains endogenous microsomes, a mild disruption procedure is required. Therefore, $\mathrm{CHO}$ cells are disrupted mechanically by passing the suspended cell pellet through a 20 -gauge needle or disruption using high-pressure homogenization (see Note 11).

5. A raw $\mathrm{CHO}$ lysate is further prepared by differential centrifugation at $10,000 \times \mathfrak{g}, 4^{\circ} \mathrm{C}$, for $10 \mathrm{~min}$. This step is required for 


\subsection{Generation of Linear Expression Templates}

the removal of cell debris, cell nuclei and cellular organelles (see Note 12). Raw lysate can be flash frozen using liquid nitrogen and stored at $-80{ }^{\circ} \mathrm{C}$ prior to further recondition steps.

6. Raw lysate is applied to a preequilibrated Sephadex G-25 column and eluted using wash buffer (see Subheading 2.1, item 9). Fractions of $1 \mathrm{~mL}$ are collected and RNA concentration is quantified by absorbance estimation using the NanoDrop 2000C. Fractions displaying an absorbance above $l$ at $260 \mathrm{~nm}$ are pooled.

7. Pooled fractions are treated with micrococcal S7 nuclease $(10 \mathrm{U} / \mathrm{mL})$ to digest and remove endogenous mRNA. The S7 nuclease has a calcium dependent digestion activity, therefore $1 \mathrm{mM}$ of $\mathrm{CaCl}_{2}$ is added to the enzyme containing eluate and incubated for $2 \mathrm{~min}$ at room temperature.

8. The enzymatic reaction is inactivated using the $\mathrm{Ca}^{2+}$ chelating regent EGTA (6.7 $\mathrm{mM}$ final concentration).

9. The energy regenerating enzyme creatine kinase $(100 \mu \mathrm{g} / \mathrm{mL}$ final concentration) is added to the lysate to enable the regeneration of ATP using creatine phosphate as a phosphate donor.

10. The final translationally active $\mathrm{CHO}$ lysate is flash frozen and stored at $-80{ }^{\circ} \mathrm{C}$ ( see Note 13).

The application of linear DNA templates to the cell-free reaction offers a fast, flexible and cost-efficient approach to produce diverse proteins with different modifications, signal peptides and protein tags. To obtain a linear DNA template suitable for $\mathrm{CHO}$ cell-free protein synthesis, a two-step PCR procedure needs to be performed to add the required regulatory sequences to a target gene. A general overview of the procedure is illustrated in Fig. 2.

1. The gene of interest is amplified using gene specific adapter primers harboring an overlap to the $5^{\prime}$ - and $3^{\prime}$ - regulatory sequences.

2. The $5^{\prime}$ - regulatory sequences, which contains a stem loop for stabilization, the T7 RNA promotor and the CRPV IGR IRES, are amplified using a regulatory sequence donor vector, Reg-F and CRPV-R primer.

3. Subsequently, the presence of both PCR products is verified on agarose gel prior to their fusion and the generation of the final linear expression template (see Note 14).

4. Fusion PCR is performed by application of both previously generated DNA fragments (gene fragment and $5^{\prime}$ - regulatory fragment) in an equimolar amount to the reaction and supplementation of regulatory primers (Reg-F and Reg-R). A highfidelity DNA dependent polymerase is used for DNA 

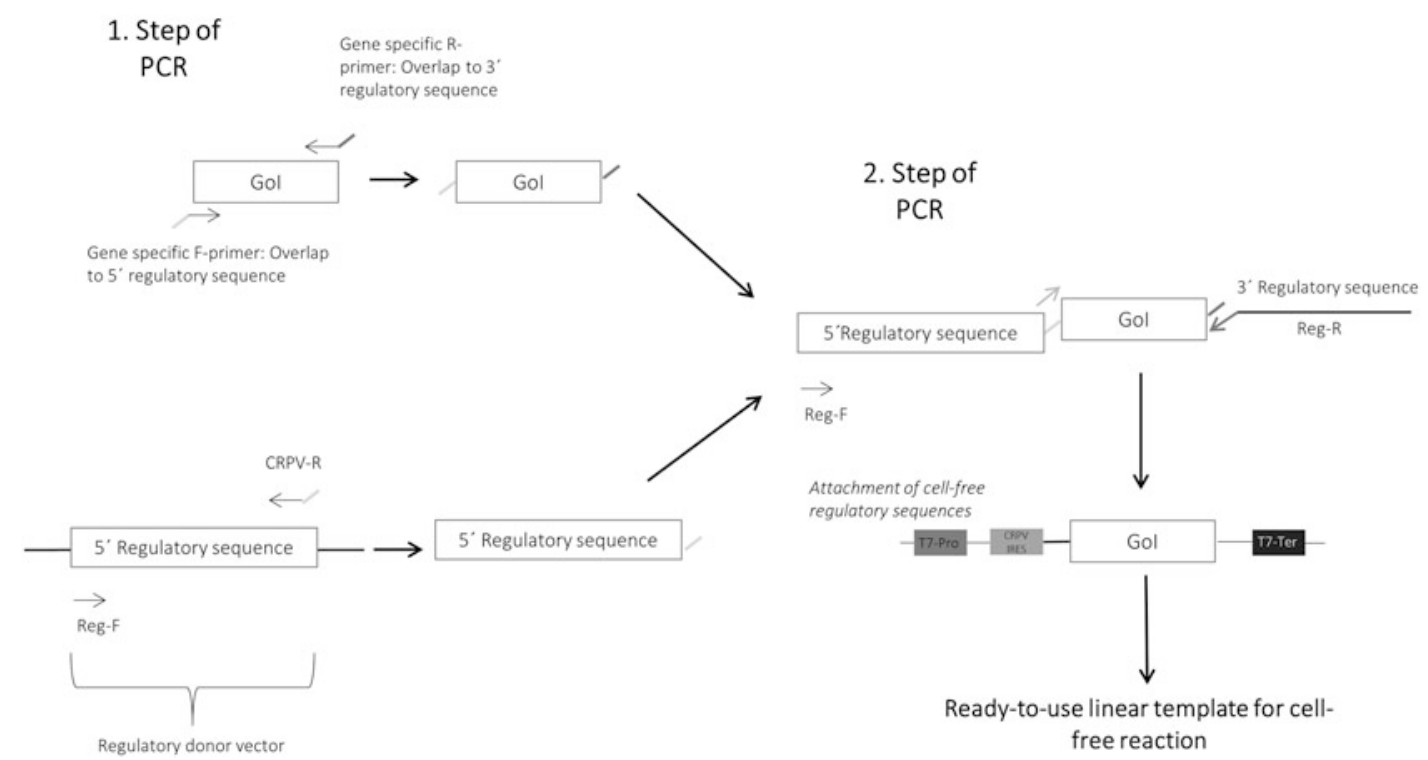

Fig. 2 Schematic overview of linear expression template generation for $\mathrm{CHO}$ cell-free synthesis. A two-step procedure is used for the generation of cell-free compatible linear DNA templates. The first step includes the amplification of the gene of interest (GOI) using gene-specific primer pairs. This step includes the fusion of overlap sequences to $5^{\prime}$ - and $3^{\prime}$ - regulatory sequences. Additionally, the $5^{\prime}$-regulatory sequence including stem loops for stabilization, the T7 RNA polymerase promotor for initiation of transcription and the Cricket paralysis virus IGR IRES for translation initiation factor independent translation initiation, is amplified using a regulatory donor vector and the Reg-F and CRPV-R primers. Both PCR products are fused during the second step of PCR using the Reg-F primer, and $3^{\prime}$-terminal regulatory sequences are added to the GOI by application of the Reg-R primer. After the second step, a ready-to-use linear DNA template for the $\mathrm{CHO}$ cell-free reaction is prepared

\subsection{Preparation of Circular Plasmid Templates}

amplification to enable a high correctness of produced DNA sequence by low misincorporation rates and proof reading activities.

5. The produced linear PCR fragment is analyzed on an agarose gel prior to the application to the cell-free reaction ( see Note 15).

6. Different signal peptides, purification tags and fluorescence tags can be integrated into the DNA sequences by the previously described procedure. For this, overlap sequences and regulatory primer pairs need be adapted to the individual requirements.

1. Transformation of the desired plasmid template into E. coli JM109 cells is performed by electroporation using a $1 \mathrm{mM}$ cuvette and a Biorad electroporation system.

2. Transformed cells are plated on agar-antibiotic plats for E. coli clone growth. Transformed E. coli cell stocks are stored in glycerol at $-80{ }^{\circ} \mathrm{C}$. 
3.5 Cell-Free

Synthesis in a BatchFormatted Reaction
3. E. coli cell clone is picked and inoculated into a shake flask containing LB medium and the appropriate antibiotics and cultured overnight at $37^{\circ} \mathrm{C}$ and $120 \mathrm{RPM}$.

4. Amplified plasmid DNA is isolated from E. coli overnight culture using the PureLink HiPure Plasmid Prep Kit (see Note 16).

5. Concentration of isolated plasmid DNA was analyzed at an absorbance of $260 \mathrm{~nm}$ using the Nanodrop 2000 C. A $260 / 280$ purity value around 1.8 is required for further applicability of the plasmid DNA to a cell-free protein synthesis reaction.

6. Gene integration is evaluated by treatment of isolated plasmid DNA with restriction enzymes and separation of obtained DNA fragments by agarose gel electrophoresis. DNA fragment size is estimated using Clone Manager Software.

7. The DNA sequence is further verified by gene sequencing using Ml3-F and Ml3-R primers.

1. All required components for cell-free protein synthesis are thawed on ice prior to their use in the reaction (see Note 17).

2. Batch formatted $\mathrm{CHO}$ cell-free reactions are performed in Eppendorf tubes containing reaction volumes from $20 \mu \mathrm{L}$ up to $500 \mu \mathrm{L}$. Reports of prokaryotic cell-free systems show the possibility for process scale up to $100 \mathrm{~L}$ reaction volume [20].

3. To prevent RNase contamination, $\mathrm{CHO}$ cell-free reactions are pipetted using filter tips.

4. The preparation of the cell-free $\mathrm{CHO}$ batch reaction is performed on ice. The general principle of the $\mathrm{CHO}$ lysate based cell-free protein synthesis is illustrated in Fig. 3a.

5. The transcription/translation coupled $\mathrm{CHO}$ cell-free batch reaction is composed of $40 \% \mathrm{CHO}$ cell lysate, $10 \%$ translation buffer and $20 \%$ energy buffer.

6. Typically, $20 \mathrm{nM}$ of plasmid DNA is added to the reaction but the optimal concentration depends on the applied vector backbone ( see Note 18).

7. To enable transcription of mRNA, $1 \mathrm{U} / \mu \mathrm{L}$ T7 RNA polymerase are supplemented to the $\mathrm{CHO}$ cell-free reaction.

8. For further analysis of produced proteins, ${ }^{14} \mathrm{C}$ leucine (specific radioactivity: $66.67 \mathrm{dpm} / \mathrm{pmol}$ ) is added to the reaction and cotranslationally incorporated into the synthesized proteins.

9. Reaction volume is adjusted by supplementation with Millipore water to the final volume. 


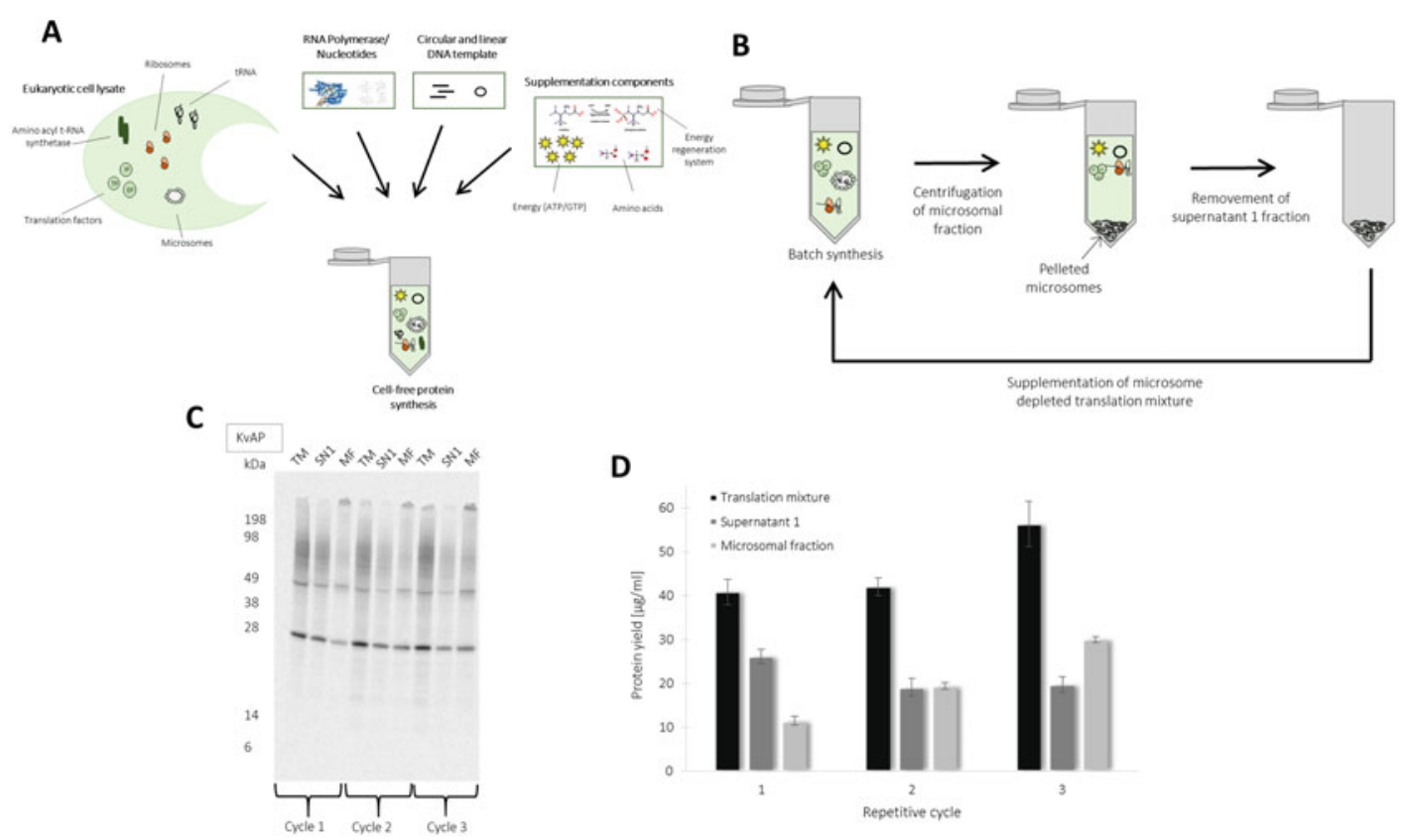

Fig. 3 Batch formatted cell-free synthesis based on $\mathrm{CHO}$ cell lysates. (a) Schematic overview of $\mathrm{CHO}$ cell-free protein synthesis using batch mode. The batch formatted cell-free protein synthesis system consists of the CHO cell lysate, T7 RNA polymerase, nucleotides, a DNA template containing the GOI, and supplementation components. The exact protocol is described in Subheading 3.5. The translation mixture can be separated into ER derived microsomes and a supernatant 1 fraction by centrifugation $\left(16,000 \times g, 4{ }^{\circ} \mathrm{C}, 15 \mathrm{~min}\right)$. The microsomal fraction contains proteins, which are cotranslationally translocated into the microsomes by signal peptide SRP-complex interaction. The microsomes enable direct integration of membrane proteins into a natural milieu having ER based posttranslational modifications. (b) describes a repetitive translation of proteins into the microsomes for enrichment of secretory and membrane embedded proteins. For this, a general cell-free reaction is performed. After finishing the reaction, microsomes are separated by centrifugation and supernatant 1 is removed. Previously addressed microsomes are supplemented with a freshly prepared translation mixture depleted of microsomes. An example for an enrichment of a membrane protein is depicted in (c) and (d). For this, the ion channel KvAP is synthesized into the microsomes using three repetitive protein production cycles in the batch formatted $\mathrm{CHO}$ cell-free system. (c) shows an autoradiograph of translations mixture (TM), supernatant 1 (SN1), and microsomal fraction (MF) of the different repetitive cycles. Appropriate monomer ( $30 \mathrm{kDa}$ ) and dimer $(60 \mathrm{kDa})$ bands of KvAP were detected. The quantification of protein yield by TCA precipitation followed by scintillation measurement showed an increase of protein yield in the microsomal fraction from around $11 \mu \mathrm{g} / \mathrm{mL}$ to approximately $30 \mu \mathrm{g} / \mathrm{mL}$ (d)

10. Optimization experiments included a further increase of T7 RNA polymerase to $3 \mathrm{U} / \mu \mathrm{L}$ and the supplementation of molecular crowding reagents (PEG, Ficoll) (see Note 19).

11. All components were pipetted directly to the reaction while adjusting the volume by adding ddH20. Standard conditions present in a batch-formatted $\mathrm{CHO}$ cell-free reaction are summarized in Table 1.

12. Ready prepared cell-free translation mixture is incubated for $3 \mathrm{~h}$ at $30^{\circ} \mathrm{C}$ and $600 \mathrm{RPM}$ using a thermomixer. 
Table 1

List of standard reaction conditions present in a batch-formatted $\mathrm{CHO}$ cell-free system: optimized conditions are indicated in bold letters

\begin{tabular}{|ll}
\hline Component/Parameter & CHO batch reaction conditions \\
\hline Cell lysate & $40 \%(\mathrm{vol} / \mathrm{vol})$ \\
\hline HEPES KOH, pH 7.6 & $30 \mathrm{mM}$ \\
\hline KoAc & $150 \mathrm{mM}$ \\
\hline $\mathrm{Mg}(\mathrm{OAc})_{2}$ & $3.9 \mathrm{mM}$ \\
\hline ATP & $1.75 \mathrm{mM}$ \\
\hline CTP,GTP,UTP & $0.3 \mathrm{mM}$ \\
\hline $\mathrm{m}^{7} \mathrm{G}(\mathrm{ppp}) \mathrm{G}$ cap $(\mathrm{cap} \mathrm{I})$ & $0.1 \mathrm{mM}$ \\
\hline Amino acids & $100 \mu \mathrm{M}$ \\
\hline${ }^{14} \mathrm{C}$ Leucine & $66.67 \mathrm{dpm} / \mathrm{pmol}$ \\
\hline Plasmid concentration & $20 \mathrm{nM}$ \\
\hline T7 RNA polymerase & $1 \mathrm{U} / \mu \mathrm{L}(\mathbf{3} \mathrm{U} / \boldsymbol{\mu L})$ \\
\hline DTT & $2.5 \mathrm{mM}$ \\
\hline PEG 1500 & $\mathbf{2 \%}$ \\
\hline Temperature & $30{ }^{\circ} \mathrm{C}$ \\
\hline Agitation & $600 \mathrm{RPM}$ \\
\hline Reaction time & $3 \mathrm{~h}$ \\
\hline
\end{tabular}

13. The $\mathrm{CHO}$ cell-free translation mixture can be directly used for further analysis of the produced protein. Cell-free synthesized proteins can be applied to various assays. Radio labeled proteins can be quantified using TCA precipitation followed by scintillation measurement.

14. Molecular weight and protein modifications can be analyzed by separation of acetone-precipitated proteins on SDS-PAGE followed by autoradiography.

15. Figure 3 shows exemplary CHO cell-free synthesis of membrane protein and ion channel KvAP. Functional membrane proteins are integrated into the ER derived microsomes of $\mathrm{CHO}$ lysate. Microsomes can be separated by centrifugation $\left(16,000 \times g, 4{ }^{\circ} \mathrm{C}, 15 \mathrm{~min}\right)$. Proteins integrated into the microsomes can be enriched by a repetitive addressing procedure. For this, a batch based cell-free reaction is initially performed followed by the separation of microsomal fraction. The separated microsomes are dissolved in a freshly prepared cellfree reaction depleted from microsomes, which enables the 


\subsection{High-Yield Production of Proteins Using a Continuous Exchange Cell-Free System}

enrichment of translocated proteins into microsomes. This procedure is performed for three repetitive cycles. A schematic overview is illustrated in Fig. $3 \mathrm{~b}$. The produced membrane protein KvAP shows the formation of monomeric and multimeric structures in the autoradiograph (Fig. 3c). An increase in produced membrane protein is detected in the microsomal fraction (Fig. 3d) (see Note 20).

1. As reported for the batch formatted cell-free reaction, all components are thawed on ice prior to their use in the reaction $(s e e$ Note 17).

2. The preparation of CECF reaction is performed on ice.

3. The CHO continuous exchange cell-free reaction is performed in a two chamber device consisting of a reaction chamber $(50 \mu \mathrm{L})$ and a feeding chamber $(1000 \mu \mathrm{L})$. A general scheme of $\mathrm{CHO}$ CECF reaction is depicted in Fig. 4a. The reaction chamber contains a general cell-free reaction, the feeding chamber includes additional energy components. Both chambers are separated by a semipermeable membrane and due to diffusion gradients energy components are continuously delivered to the reaction chamber and inhibitory byproducts are removed from the reaction chamber. Thereby, protein production time is prolonged resulting in an increased protein yield. Analysis of reactor membrane cut-off by CECF synthesis of membrane protein EGFR fused to a C-terminal eYFP, results in an optimal protein yield using a membrane cut-off between 10 and $14 \mathrm{kDa}$ in comparison to smaller cut-offs $(3-8 \mathrm{kDa})$ (Fig. 4b) (see Note 21).

4. Feeding and reaction mix are prepared separately.

5. The feeding mix consists of $1 \times$ translation buffer and $1 \times$ energy buffer harboring the conditions described in Table 2. Additionally, $0.02 \%$ sodium azide (see Note 22), caspase inhibitor Ac-DEVD-CMK $(30 \mu \mathrm{M}),{ }^{14} \mathrm{C}$ leucine $(9.9 \mathrm{dpm} / \mathrm{pmol})$, and $\mathrm{ddH}_{2} \mathrm{O}$ (filling up to $1000 \mu \mathrm{L}$ ) are added to complete the feeding mixture.

6. The reaction mix is then prepared. The optimized conditions of the reaction mix differ from the standard $\mathrm{CHO}$ cell-free batch reaction and are illustrated in Table 2. Essential parameters which differ from the standard conditions are the concentration of $\mathrm{Mg}(\mathrm{OAC})(22 \mathrm{mM})$, creatine phosphate (18.5 mM), caspase inhibitor Ac-DEVD-CMK $(30 \mu \mathrm{M})$, plasmid concentration $(30 \mathrm{nM})$, and ${ }^{14} \mathrm{C}$ leucine $(9.9 \mathrm{dpm} / \mathrm{pmol})$.

7. The reaction mixture is transferred into the dialysis device followed by the feeding mix. 
A

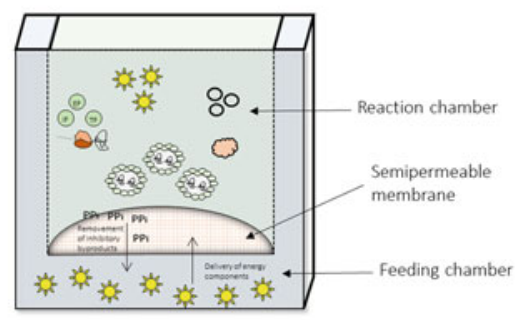

C

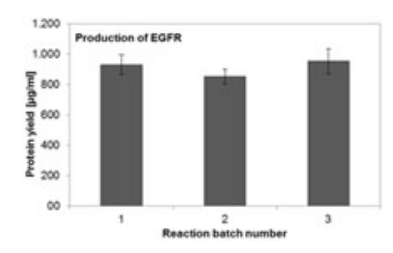

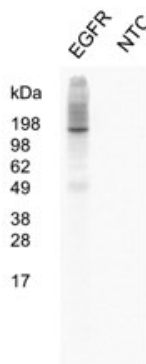

B

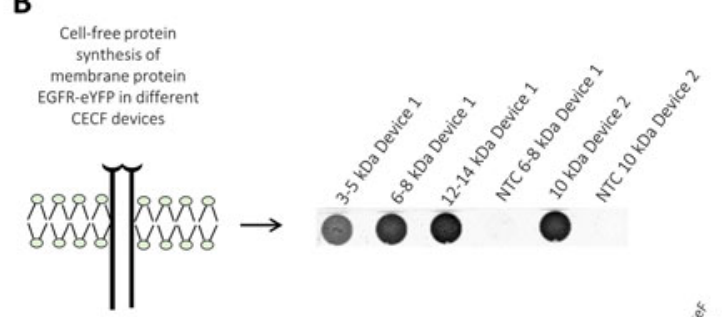

D

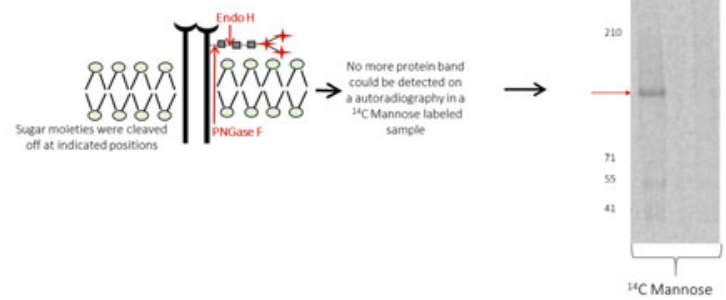

Fig. 4 Continuous exchange cell-free synthesis based on $\mathrm{CHO}$ cell lysates. (a) Schematic overview of the general principle of the CHO CECF reaction. The reaction vessel is divided into a reaction chamber and a feeding chamber, separated by a semipermeable membrane. The membrane protein EGFR fused to a C-terminal eYFP is used as a model protein for CHO CECF synthesis. The cut-off of the dialysis membrane is analyzed using different dialysis devices (device 1 (Scienova); device 2 (RiNA GmbH)). Fluorescence intensity of the produced EGFR-eYFP fusion protein was analyzed on $\mu$-lbidi-Slides using a multimode imager (Typhoon Trio Plus, GE Healthcare). An increase in protein fluorescence was achieved using a cut-off between 10 and $14 \mathrm{kDa}$ compare to a smaller cut-off (3-8 kDa) (b). For further experiments, device 2 was used. After optimizing the reaction conditions (Table 2), protein yields of approximately $1000 \mu \mathrm{g} / \mathrm{mL}$ of "difficult-toexpress" protein EGFR were obtained in different reaction batches (c). The quantification of protein yield was performed by TCA precipitation followed by scintillation measurement. An appropriate protein band is detected on the autoradiograph, while no band is detected in the sample containing no DNA template (NTC). The glycosylation of the protein was verified by the supplementation of ${ }^{14} \mathrm{C}$ mannose during the $\mathrm{CHO}$ CECF reaction and further analysis by autoradiography (d). Glyco residues were removed by EndoH and PNGaseF treatment to underline the specificity of the glycosylation band

8. The device is sealed with plastic foil and placed into a thermomixer $\mathrm{C}$ for incubation at $30^{\circ} \mathrm{C}, 600 \mathrm{RPM}$ and $48 \mathrm{~h}$.

9. After finishing the CECF synthesis, the sealing is removed and reaction mixture is transferred into an Eppendorf tube for further analysis.

10. Like reported for the batch based cell-free reaction, reaction mixture can be directly used for the analysis of the produced proteins. Different batches of CECF synthesized membrane protein EGFR were quantified and analyzed using autoradiography (Fig. 4c). 


\section{Table 2}

List of standard reaction conditions present in a CHO CECF system

\begin{tabular}{llll}
\hline Component/Parameter & CHO CECF reaction conditions & Reaction mix & Feeding mix \\
\hline Cell lysate & $40 \%(\mathrm{Vol} / \mathrm{Vol})$ & $\times$ & \\
\hline HEPES KOH, pH 7.6 & $30 \mathrm{mM}$ & $\times$ & $\times$ \\
\hline $\mathrm{KoAc}$ & $150 \mathrm{mM}$ & $\times$ & $\times$ \\
\hline $\mathrm{Mg}(\mathrm{OAc})_{2}$ & $3.9 \mathrm{mM}$ & & \\
\hline $\mathrm{Mg}(\mathrm{OAc})_{2}$ & $22 \mathrm{mM}$ & $\times$ & $\times$ \\
\hline $\mathrm{ATP}$ & $1.75 \mathrm{mM}$ & $\times$ & $\times$ \\
\hline CTP,GTP,UTP & $0.3 \mathrm{mM}$ & $\times$ & $\times$ \\
\hline Amino acids & $100 \mu \mathrm{M}$ & $\times$ & $\times$ \\
\hline $14 \mathrm{C}$ Leucine & $9.9 \mathrm{dpm} / \mathrm{pmol}$ & $\times$ & $\times$ \\
\hline Sodium azide & $0.02 \%$ & $\times$ & \\
\hline Plasmid & $30 \mathrm{nM}$ & $\times$ & $\times$ \\
T7 RNA polymerase & $1 \mathrm{U} / \mu \mathrm{L}$ & $\times$ & $\times$ \\
\hline DTT & $2.5 \mathrm{mM}$ & $\times$ & $\times$ \\
\hline Caspase inhibitor Ac-DEVD-CMK & $30 \mu \mathrm{M}$ & $\times$ & $\times$ \\
\hline Temperature & $30{ }^{\circ} \mathrm{C}$ & $\times$ & $\times$ \\
\hline Agitation & $600 \mathrm{RPM}$ & $\times$ & $\times$ \\
\hline Reaction time & $48 \mathrm{~h}$ & & \\
\hline
\end{tabular}

11. The quantification was performed using $3 \mu \mathrm{L}$ of reaction mixture for hot TCA precipitation and further analysis by scintillation measurement. Typically, protein yields of approximately $1000 \mu \mathrm{g} / \mathrm{mL}$ are obtained. An autoradiograph of EGFR shows the expected molecular weight at around $170 \mathrm{kDa}$.

12. Protein glycosylation can be monitored by adding $3 \mathrm{nM}{ }^{14} \mathrm{C}$ mannose to the CHO CECF reaction.

13. After finishing cell-free protein synthesis, ${ }^{14} \mathrm{C}$ mannose labeled sample is acetone precipitated and can be directly applied to SDS-PAGE.

14. The dried gel is analyzed by autoradiography.

15. For the purpose of verifying the specificity of protein glycosylation, a treatment of CHO CECF sample using glycosidases PNGaseF (NEB) and EndoH (NEB) is performed according to the manufacturer's protocol. The results show the specificity of EGFR glycosylation performed in the CHO CECF system (Fig. 4d). 
3.7 Application of Linear Expression Templates to $\mathrm{CHO}$ CellFree Systems
The application of linear expression templates to a $\mathrm{CHO}$ cell-free system offers new possibilities for fast and easy template generation and modification. This procedure is mandatory for cloning-free high-throughput applications and the development of novel screening technologies for the production and analysis of difficult-to-express proteins.

1. For the application of PCR products to the $\mathrm{CHO}$ cell-free reactions, standard batch formatted as well as CECF reactions are performed. Plasmid DNA is replaced by previously prepared linear expression template.

2. The productivity of batch cell-free systems based on linear expression templates are strongly dependent on the concentration of applied PCR-product. Figure 5 a shows the dependency of PCR product concentration on the received protein yield in a batch formatted $\mathrm{CHO}$ cell-free reaction for the production of secreted protein EPO. A maximum protein yield is obtained by the application of $12.5 \mathrm{ng} / \mu \mathrm{L}$ linear expression template to the batch formatted $\mathrm{CHO}$ cell-free protein synthesis system.
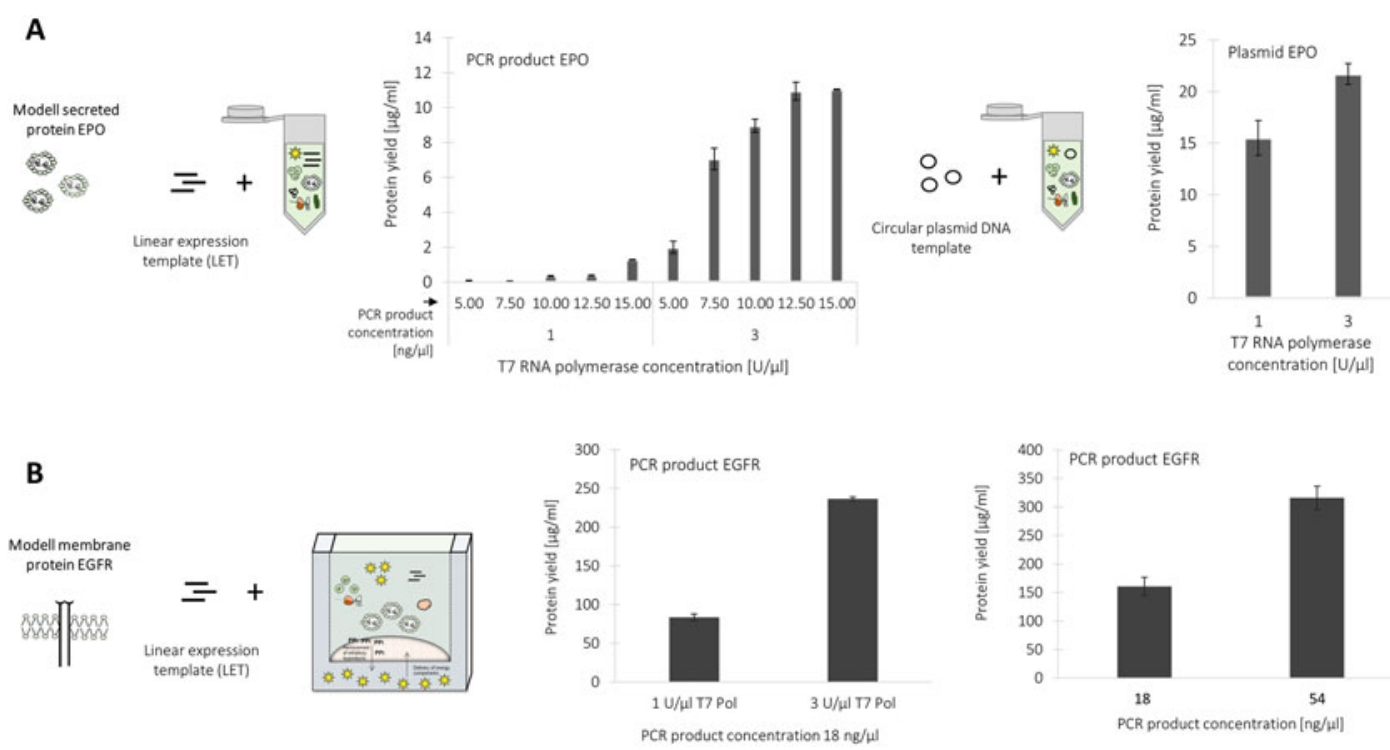

Fig. 5 Application of linear expression DNA templates to $\mathrm{CHO}$ cell-free protein synthesis systems. (a) Linear expression templates (LET) of secreted protein EPO were applied to a batch formatted $\mathrm{CHO}$ cell-free protein synthesis system. An increase of protein yield was detected by increasing the PCR product and T7 RNA polymerase concentrations. Protein yields up to approximately $12 \mu \mathrm{g} / \mathrm{mL}$ were obtained as compared to $22 \mu \mathrm{g} / \mathrm{mL}$ using a plasmid DNA template. (b) Linear expression templates of membrane protein EGFR were applied to a CHO CECF system. An influence of T7 RNA polymerase and PCR product concentrations on the productivity of the protein was detected. An increase of T7 RNA polymerase and PCR production lead to protein yields up $350 \mu \mathrm{g} / \mathrm{mL}$ of EGFR using a PCR product as a DNA expression template. Protein yields were derived by TCA precipitation of radio labeled proteins followed by scintillation measurement 
3. An increase in T7 RNA polymerase concentration from $1 \mathrm{U} / \mu$ $\mathrm{L}$ to $3 \mathrm{U} / \mu \mathrm{L}$ results in a significant increase in protein yield in the batch system. Protein yields up to approximately $12 \mu \mathrm{g} / \mathrm{mL}$ of secretory EPO were obtained by a combined increase of T7 RNA polymerase and PCR product concentration (Fig. 5a) (see Note 23).

4. The application of linear DNA templates to the CHO CECF system requires an increase of T7 RNA polymerase and PCR product concentration as reported for the batch formatted system. A maximum protein yield of $350 \mu \mathrm{g} / \mathrm{mL}$ of membrane protein EGFR was obtained using $3 \mathrm{U} / \mu \mathrm{L}$ and $54 \mathrm{ng} / \mu \mathrm{L}$ of linear PCR product.

\section{Notes}

1. Serum-free and chemically defined media are used for the cultivation of $\mathrm{CHO}$ cells prior to their utilization in lysate production procedure. This enables low batch-to-batch variation and therefore a high reproducibility in the cultivation step for the subsequent production of translationally active $\mathrm{CHO}$ cell lysates.

2. Aeration and stirring conditions in the bioreactor for the production of $\mathrm{CHO}$ cell biomass are adapted to obtain a stress reduced cultivation procedure. Induction of cell stress response can lead to inactivation of translation factors due to kinase dependent phosphorylation reactions and activation of the cell death response including the overexpression of caspases, a class of cysteinyl-aspartate specific proteases that reportedly cleave translation factors thereby reducing the productivity of the protein translation machinery.

3. All cultivation relevant parameters were directly implemented into MFCS SCADA bioprocess software. Thereby growth relevant values can be directly monitored to estimate the point of harvest of the biomass for lysate production. $\mathrm{CHO}$ cells harvested in the late log phase resulted in the highest translational activity of produced cell lysates.

4. Cultured CHO cells were microscopically analyzed during cell cultivation, after harvesting and washing procedures, and after cell disruption to verify cell stress response by the morphology of cells and the degree of cell disruption.

5 . The regulatory sequence donor vector contains the $5^{\prime}$ regulatory sequences required for transcription and translation reaction including the Cricket Paralysis Virus IGR IRES and the T7 RNA polymerase promotor. 
6. Regulatory overlap sequences consist of $10-15$ base pairs complementary to the $3^{\prime}$ end of the CRPV IGR IRES for the $\mathrm{N}$-terminal gene specific primer and a 10 base pair overlap to the T7 terminator for the $\mathrm{C}$-terminal gene specific primer.

7. The HotStar HiFidelity DNA polymerase is a hot-start proofreading enzyme, which enables the amplification of PCR-products with a minimized rate of mutation incorporation. Factor $\mathrm{SB}$ in the PCR buffer prevents degradation of primers and DNA-template during PCR.

8. The EasyXpress pIX3.0 cell-free expression vector backbone contains regulatory $\mathrm{N}$ - and $\mathrm{C}$-terminal sequences for the application in various prokaryotic and eukaryotic cell-free protein synthesis systems.

9. Repeated freeze/thaw cycle (up to 5 times) does not affect the quality of the translation and energy buffers. Ready prepared CHO lysate shows no loss of activity by three repeated freeze/ thaw cycles.

10. The caspase inhibitor is initially dissolved in DMSO to increase its stability during freezing and storage. For the application to the cell-free synthesis reaction, the caspase inhibitor is further diluted in water.

11. The degree of cell disruption is monitored by microscopic imaging. If a high degree of intact cells is present after initial disruption, a repetition of the cell disruption step is performed.

12. If intact cells are available after cell disruption, these cells will be removed by the centrifugation step due to their sedimentation coefficient.

13. The ready prepared raw lysate can be stored for more than 5 years at $-80^{\circ} \mathrm{C}$ without significant loss of activity.

14. $1 \mu \mathrm{L}$ of the PCR sample is diluted in $2 \mu \mathrm{L}$ of sample buffer and $9 \mu \mathrm{L}$ of Millipore water and loaded onto a $1 \%$ agarose gel. The agarose gel is run for $60 \mathrm{~min}$ at $100 \mathrm{~V}$ for the separation of DNA samples. Detection of DNA was accomplished using DNA intercalating dye DNA safe stain and an UV detection unit.

15. For application of a linear expression template to a cell-free reaction no further purification of the PCR product is required.

16. The preparation of plasmid DNA is performed according to the manufacture's protocol.

17. Thawing of cell-free components on ice enables a mild and slow thaw procedure which prevents the degradation and inactivation of enzymatic and translation related components. 
18. Apart from the standardized pIX3.0 cell-free expression vector, various vector backbones can be applied to the $\mathrm{CHO}$ cell-free synthesis reaction. Requirements for the application to the $\mathrm{CHO}$ cell-free reaction are the presence of a T7 RNA polymerase promotor/terminator and an IRES sequence. Optimal concentrations of the plasmid depend on the type of plasmid applied. It is mandatory to evaluate each individual vector backbone to obtain increased protein yields.

19. Supplementation of PEG and Ficoll induce molecular crowding effects, which lead to an increased activity of T7 RNA polymerase.

20. Autoradiographs are prepared after separation of protein samples on SDS-PAGE. The SDS-PAGE is dried on an unigel dryer and exposed on a phosphor-screen for 3 days. The autoradiography is completed using a multimode imager (Typhoon Trio Plus, GE-Healthcare).

21. The evaluation of fluorescent proteins was performed using a multimode imager. For this, $5 \mu \mathrm{L}$ of cell-free produced protein sample is diluted with $20 \mu \mathrm{L}$ PBS and directly applied to an $\mu$-Ibidi slide. The Ibidi slide can be placed in the multimode imager for fluorescence imaging.

22. Sodium azide is a supplement for the CHO CECF reaction to prevent microbial contamination.

23. The application of linear expression templates to a cell-free system generally leads to decreased protein yields compared to a circular DNA expression template. This fact is due to the decreased stability of linear DNA templates in cell-free systems.

\section{Acknowledgments}

This work was supported by Fraunhofer High Performance Center for Functional Integration in Materials, the European Regional Development Fund (EFRE), and the German Ministry of Education and Research (BMBF, No. 031B0078A).

\section{References}

1. Bandaranayake AD, Almo SC (2013) Recent advances in mammalian protein production. FEBS Lett 588(2):253-260. https://doi.org/ $10.1016 /$ j.febslet.2013.11.035

2. Merlin M, Gecchele E, Capaldi S, Pezzotti M, Avesani L (2014) Comparative evaluation of recombinant protein production in different biofactories: the green perspective. Biomed Res Int 2014:14. https://doi.org/10.1155/ 2014/136419
3. Kim JY, Kim Y-G, Lee GM (2012) CHO cells in biotechnology for production of recombinant proteins: current state and further potential. Appl Microbiol Biotechnol 93 (3):917-930. https://doi.org/10.1007/ s00253-011-3758-5

4. Lai T, Yang Y, Ng SK (2013) Advances in mammalian cell line development technologies for recombinant protein production. 
Pharmaceuticals 6(5):579-603. https://doi. org/10.3390/ph6050579

5. Harvey AL (2014) Toxins and drug discovery. Toxicon 92:193-200. https://doi.org/10. 1016/j.toxicon.2014.10.020

6. Yin H, Flynn AD (2016) Drugging membrane protein interactions. Annu Rev Biomed Eng 18:51-76. https://doi.org/10.1146/ annurev-bioeng-092115-025322

7. Carlson ED, Gan R, Hodgman CE, Jewett MC (2012) Cell-free protein synthesis: applications come of age. Biotechnol Adv 30 (5):1185-1194. https://doi.org/10.1016/j. biotechadv.2011.09.016

8. Chong S (2014) Overview of cell-free protein synthesis: historic landmarks, commercial systems, and expanding applications. Curr Prot Mol Biol 108:16.30.1-16.30.11. https://doi. org/10.1002/0471142727.mbl630s108

9. Lu Y (2017) Cell-free synthetic biology: engineering in an open world. Synth Syst Biotechnol 2(1):23-27. https://doi.org/10.1016/j. synbio.2017.02.003

10. Zemella A, Thoring L, Hoffmeister C, Kubick $S$ (2015) Cell-free protein synthesis: pros and cons of prokaryotic and eukaryotic systems. Chembiochem 16(17):2420-2431. https:// doi.org/10.1002/cbic.201500340

11. Brodel AK, Wustenhagen DA, Kubick S (2015) Cell-free protein synthesis systems derived from cultured mammalian cells. Methods $\mathrm{Mol}$ Biol 1261:129-140. https://doi.org/10. 1007/978-1-4939-2230-7_7

12. Buntru M, Vogel S, Stoff K, Spiegel H, Schillberg $S$ (2015) A versatile coupled cell-free transcription-translation system based on tobacco BY-2 cell lysates. Biotechnol Bioeng 112 (5):867-878. https://doi.org/10.1002/bit. 25502

13. Hodgman CE, Jewett MC (2013) Optimized extract preparation methods and reaction conditions for improved yeast cell-free protein synthesis. Biotechnol Bioeng 110(10):2643-2654 . https://doi.org/10.1002/bit.24942
14. Kubick S, Schacherl J, Fleischer-Notter H, Royall E, Roberts LO, Stiege W (2003) In vitro translation in an insect-based cell-free system. In: Swartz JR (ed) Cell-free protein expression. Springer, Berlin, Heidelberg, pp 209-217

15. Brodel AK, Sonnabend A, Kubick S (2014) Cell-free protein expression based on extracts from $\mathrm{CHO}$ cells. Biotechnol Bioeng 111 (1):25-36. https://doi.org/10.1002/bit. 25013

16. Brodel AK, Sonnabend A, Roberts LO, Stech M, Wüstenhagen DA, Kubick S (2013) IRES-mediated translation of membrane proteins and glycoproteins in eukaryotic cell-free systems. PLoS One 8(12):e82234. https:// doi.org/10.1371/journal.pone.0082234

17. Ogonah OW, Polizzi KM, Bracewell DG (2017) Cell free protein synthesis: a viable option for stratified medicines manufacturing. Curr Opin Chem Eng 18:77-83. https://doi. org/10.1016/j.coche.2017.10.003

18. Thoring L, Wustenhagen DA, Borowiak M, Stech M, Sonnabend A, Kubick S (2016) Cell-free systems based on $\mathrm{CHO}$ cell lysates: optimization strategies, synthesis of "difficultto-express" proteins and future perspectives. PLoS One 11(9):e0163670. https://doi.org/ 10.1371/journal.pone.0163670

19. Thoring L, Dondapati SK, Stech M, Wüstenhagen DA, Kubick S (2017) High-yield production of "difficult-to-express" proteins in a continuous exchange cell-free system based on CHO cell lysates. Sci Rep 7(1):11710. https:// doi.org/10.1038/s41598-017-12188-8

20. Zawada JF, Yin G, Steiner AR Yang J, Naresh A, Roy SM, Gold DS, Heinsohn HG, Murray CJ (2011) Microscale to manufacturing scale-up of cell-free cytokine production--a new approach for shortening protein production development timelines. Biotechnol Bioeng 108(7):1570-1578. https://doi.org/10.1002/bit.23103

Open Access This chapter is licensed under the terms of the Creative Commons Attribution 4.0 International License (http://creativecommons.org/licenses/by/4.0/), which permits use, sharing, adaptation, distribution and reproduction in any medium or format, as long as you give appropriate credit to the original author(s) and the source, provide a link to the Creative Commons license and indicate if changes were made.

The images or other third party material in this chapter are included in the chapter's Creative Commons license, unless indicated otherwise in a credit line to the material. If material is not included in the chapter's Creative Commons license and your intended use is not permitted by statutory regulation or exceeds the permitted use, you will need to obtain permission directly from the copyright holder. 